RUTMech, t. XXXIII, z. 88 (4/16), październik-grudzień 2016, s. 299-306

Tadeusz BALAWENDER ${ }^{1}$

Lukasz MICAL ${ }^{2}$

\title{
INFLUENCE OF FRICTION STIR WELDING TOOL GEOMETRY ON TENSILE STRENGTH OF THE JOINT
}

\begin{abstract}
Due to specific mechanical properties 2024 aluminum alloy is ideally suited for application in aerospace and automobile industries and because of its poor weldability is not widely used in other industries. To overcome this problem, a series of friction stir welding (FSW) experiments were conducted on 2024 aluminum alloy sheets by varying tools and key parameters of the process, i.e., rotation speed and travel rate of the weld tool. To investigate the influence of FSW process parameters on the mechanical strength of the joint, the tensile strength of the joint was examined as a function of FSW parameters for each tool. Optimum values of tool rotation speed and advance speed were determined for each tool and finally the optimum tool has been found.
\end{abstract}

Keywords: friction stir welding, FSW tool geometry, 2024 aluminium alloy, tensile test

\section{Introduction}

Friction stir welding (FSW) is interested joining technology for modern aerospace industry for high performance structural applications. This technology enables the joining of highly alloyed aluminum alloys series $2 \mathrm{xxx}$ and $7 \mathrm{xxx}$. These alloys are generally classified as non-weldable because of the poor solidification microstructure and porosity in the fusion zone [1]. The idea of the FSW process is quite simple: a rotating tool is immersed into joined materials and is forced to move down the joint line. The tool movement provides frictional heating, what results in the material softening and enables stirring action to join the workpiece materials together. Typical structure of the FSW joint is shown in Figure 1. It consists of two main regions: thermomechanically affected zone (TMAZ) and heat affected zone (HAZ). Within the TMAZ there is the weld nugget zone where the material undergoes severe

${ }^{1}$ Autor do korespondencji/corresponding author: Tadeusz Balawender, Politechnika Rzeszowska, al. Powstańców Warszawy 8, 35-959 Rzeszów, Poland, e-mail: tbalaw@prz.edu.pl

2 Łukasz Micał, Politechnika Rzeszowska, e-mail: d297@stud.prz.edu.pl 
plastic deformation with a fine, equiaxial, recrystallized grain microstructure. The TMAZ can be considered as a fusion zone of a conventional weld, except that melting does not occur and material is only mechanically worked. The HAZ is similar to the same zone in conventional fusion welding and its microstructure influences material properties (its initial heat treatment and microstructural phenomena like, e.g. precipitate coarsening, precipitate dissolution, recrystallization, grain growth and others [2]).

Complicated geometry of the shoulder and the pin increases the quantity of material deformed and growth of the quality of friction stir welds by improving mixing. The pin is responsible for the material flow during friction stir welding which affects the microstructure and properties of the joint. Pin may have a different shape, the most popular are cylindrical and conical, with or without thread. The length of the pin should be slightly shorter than the thickness of the workpiece while the diameter of the shoulder is always longer than the diameter of the pin. During FSW process the tool heats up to the temperatures close to the melting of the welded material. Thus, appropriate choice of the material for the tool depends on the properties of connecting materials. The friction stir tool must have following properties such as stiffness, good wear resistant, durability, high temperature strength and good toughness [3]. The most commonly used material for the tool is hot-work tool steel. This steel is easily machined, readily available and fulfills the requirements for friction stir welding of aluminum alloys, magnesium alloys and copper alloys. Other tool materials for FSW process are high speed steel, Ni-based superalloys (Inconel), sintered carbide and cermets [1]. In the work [4], the ultrafinegrained and nanocrystalline WC-Co cermet were used to FSW process of aluminum alloys. Cermet components play an essential role due to their properties. Tungsten carbide (WC) has exceptional hardness and wear/erosion resistance. Cobalt matrices are ductile and greatly improve its toughness so that brittle fracture can be avoided and the material is apparently also insensitive to sudden changes in temperature and load during welding.

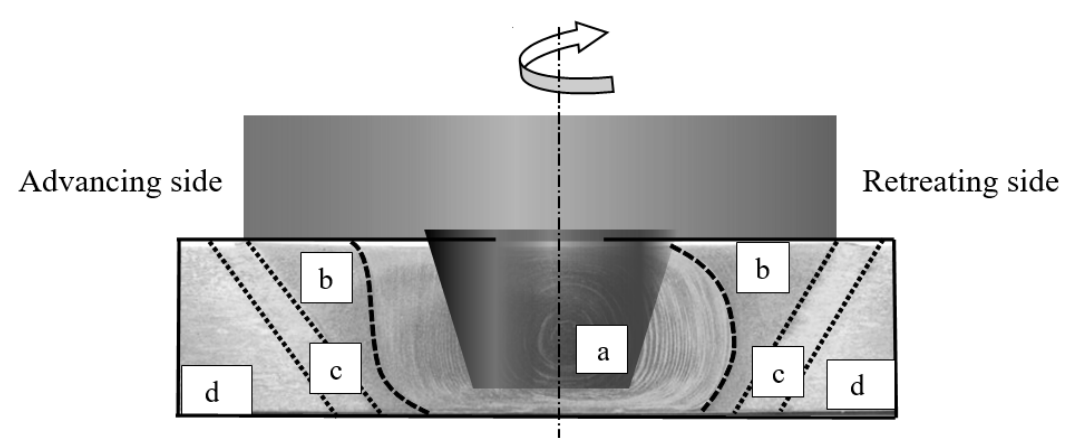

Fig. 1. Typical structure of FSW joint: a) stirred "nugget" zone, b) thermomechanically affected zone, (c) heat affected zone and d) unaffected base metal 
The FSW tool's geometry is very important for material heating and its flow in the joint region. The tool consists of two parts: a shoulder and a pin. There are two primary functions of the tool: heating of the workpiece and movement of the material to produce the joint. The heating is the result of friction between the tool and the workpiece surface and the plastic deformation of the workpiece [1-3]. The contribution of plastic deformation in heating of the material was estimated in the work [5] using numerical simulations as the ratio of plastic/frictional dissipation about 0.29 . The FSW tools differ from each other in terms of shoulder surface geometry and the shape of the pin. The tool shoulder produces most of frictional and deformational heating in the case of welding thin sheet of materials whereas the pin produces most of the heat during welding thick materials [3]. The shape and dimensions of the tool determine the volume of the heated material. The different shapes of the tool shoulder surface are shown in Figure 2 and as it can be seen the shoulder features can consist of scrolls, ridges or knurling, grooves and concentric circles, and can be machined onto any tool shoulder profile.
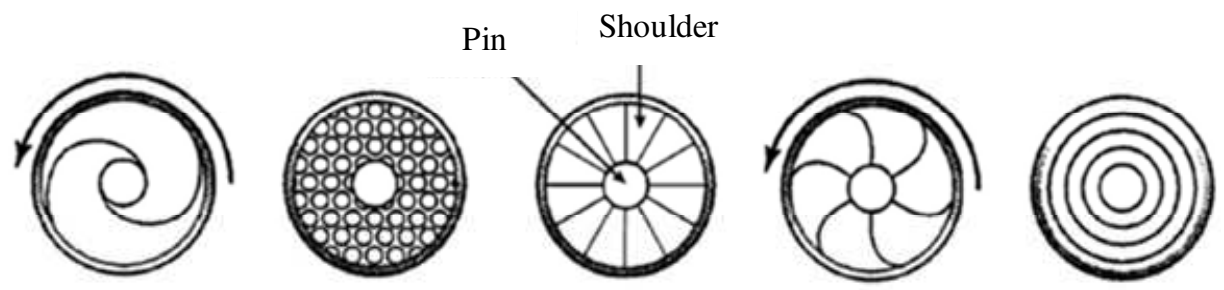

Fig. 2. Geometries of tool shoulder

\section{Experimental procedure}

The FSW experiments were conducted on $2024 \mathrm{~T} 3$ aluminum alloy sheets with a thickness of $1.6 \mathrm{~mm}$ by varying tools and key parameters of the process, i.e., rotation speed and travel rate of the weld tool. All tools used in the experiments had scrolled shoulders and threaded pins with three flutes as shown in Fig. 3. The tool number N4 had a cylindrical pin and the tools number N7 and N2 had conical pins; there were the differences in pin and shoulder diameters, too (Fig. 3). The tool material was high speed steel grade HS18-0-1. The friction stir butt joints were made on the numerical control milling machine (Makino PS95), what allows to keep an accurate positioning of the tool and repeatability of the welding conditions. The angle of tool tilt was equal to 0 and the plunge depth of the pin into the specimen was $1.45 \mathrm{~mm}$ (it is equal to about the pin length).

To make the friction stir welds the procedure was as follows: 1- two pieces of sheets (dimensions of each piece: width $100 \mathrm{~mm}$, length $200 \mathrm{~mm}$ ) to be joined were clamped on a backing plate, 2- the rotating tool was plunged into 
to the surface of joined sheets until the tool shoulder contacted with upper sheet surface, 3- the rotating tool moved along the centerline forming a joint. This procedure was repeated for each tool and the process parameters. No initial surface preparation was done. The tool rotation speed and the advance speed were in the range from 1000 to $2250 \mathrm{rev} / \mathrm{min}$ and from 50 to 100 $\mathrm{mm} / \mathrm{min}$, respectively (Table 1 ). The ratio of these parameters was named "the weld pitch" in the following text. The axial force applied to rotating tool was not measured during the welding because the milling machine was not equipped with such instrumentation. But the value of axial force results from plunged pin positioning and it was constant in all tests.

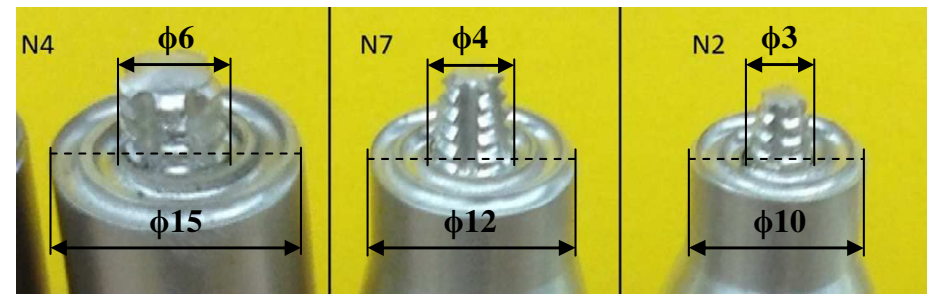

Fig. 3. Three tools used in the tests

A tensile test was used to estimate the strength of the obtained joints. The specimens for the tensile test were cut perpendicularly to the welding directions (the joint line) using a guillotine cutting machine; their width was about $12.5 \mathrm{~mm}$, length $200 \mathrm{~mm}$. The tensile tests were realized using a Zwick Roell ZO30 tensile testing machine at the displacement speed $10 \mathrm{~mm} / \mathrm{min}$. The gauge length was established on $50 \mathrm{~mm}$. The tensile tests were carried out about one week after friction stir welding of the specimens. During this time the natural stabilization aging at room temperatures was realized because of solutioning phenomena which could occur in some zones of the welded region.

\section{Results and discussion}

The main focus of the investigation was to determine the influence of tool geometry and process parameters on the mechanical behavior of the FSW joint. Welding parameters used in experiments and tensile test results are shown in Table 1. Not in all cases of weld parameters the obtained welds were of a good quality. Such bad results are not shown in Table 1; there is a dash instead of tensile strength. When the table cell is empty, it means that the test for this weld case was not carried out (a number of weld V). The setting-up of results for each tool versus the weld pitch is shown in Figure 4. The weld pitch was defined as the tool advance speed per rotation and its unit is revolution per millimetre (rev/mm). 
Table 1. Welding parameters and tensile test results

\begin{tabular}{|c|c|c|c|c|c|c|}
\hline \multirow[b]{2}{*}{$\begin{array}{l}\text { Number } \\
\text { of weld }\end{array}$} & \multicolumn{2}{|c|}{ Weld parameters } & \multirow[b]{2}{*}{$\begin{array}{l}\text { Weld pitch } \\
\text { rotation/advance } \\
\text { rev/mm }\end{array}$} & \multirow[b]{2}{*}{ Tool } & \multirow{2}{*}{$\begin{array}{c}\text { Ultimate } \\
\text { tensile strength } \\
\mathrm{R}_{\mathrm{m}} \\
\mathrm{MPa}^{*}\end{array}$} & \multirow[b]{2}{*}{$\begin{array}{c}\text { Standard } \\
\text { deviation } \\
\mathrm{MPa}\end{array}$} \\
\hline & $\begin{array}{l}\text { Speed of } \\
\text { rotation } \\
\mathrm{rev} / \mathrm{min}\end{array}$ & $\begin{array}{l}\text { Advance } \\
\mathrm{mm} / \mathrm{min}\end{array}$ & & & & \\
\hline \multirow{3}{*}{ I } & \multirow{3}{*}{1200} & \multirow{3}{*}{50} & \multirow{3}{*}{24} & $\mathrm{~N} 2$ & 323 & 18 \\
\hline & & & & N4 & 291 & 62 \\
\hline & & & & N7 & 368 & 17 \\
\hline \multirow{3}{*}{ II } & \multirow{3}{*}{1600} & \multirow{3}{*}{70} & \multirow{3}{*}{23} & $\mathrm{~N} 2$ & 310 & 15 \\
\hline & & & & N4 & 375 & 28 \\
\hline & & & & N7 & 369 & 8 \\
\hline \multirow{3}{*}{ III } & \multirow{3}{*}{1600} & \multirow{3}{*}{100} & \multirow{3}{*}{16} & $\mathrm{~N} 2$ & 289 & 27 \\
\hline & & & & N4 & - & - \\
\hline & & & & N7 & 365 & 17 \\
\hline \multirow{3}{*}{ IV } & \multirow{3}{*}{2000} & \multirow{3}{*}{50} & \multirow{3}{*}{40} & $\mathrm{~N} 2$ & 287 & 30 \\
\hline & & & & N4 & 334 & 14 \\
\hline & & & & N7 & 386 & 5 \\
\hline & & & & $\mathrm{N} 2$ & & \\
\hline \multirow[t]{2}{*}{$\mathrm{V}$} & 1000 & 80 & 12.5 & N4 & & \\
\hline & & & & N7 & 390 & 4 \\
\hline \multirow{3}{*}{ VI } & \multirow{3}{*}{2250} & \multirow{3}{*}{100} & \multirow{3}{*}{22.5} & $\mathrm{~N} 2$ & 333 & 16 \\
\hline & & & & N4 & - & - \\
\hline & & & & N7 & 265 & 3 \\
\hline
\end{tabular}

The specific weld energy is correlated with the weld pitch [2]. As it can be seen the biggest tensile strength for N2 tool was obtained for weld pitch equal $22.5 \mathrm{rev} / \mathrm{mm}$, but in this pitch case, the lower strength was obtained for N7, and N4 tool did not make sufficiently good joint at all (Figure 5). Such result in the case of tool $\mathrm{N} 4$, can be the reason of overheating the joined materials in the weld zone (great rotation speed and tool dimensions). For the tool number N7 the highest values of tensile strength were obtained when weld pitch was $40 \mathrm{rev} / \mathrm{mm}$ (it means the lowest strength for N2) and $12.5 \mathrm{rev} / \mathrm{mm}$. This can prove that it is possible, for aluminum alloy $2024 \mathrm{~T} 3$, to obtain stable FSW joint in a broad range of weld pitches, although the specific weld energy should be different for each weld pitch. The FSW joints made with a tool N4 were the most defective one, so only in three cases the joint quality was sufficiently good. Supposed reason of this may be the biggest size of pin and shoulder which due to friction phenomena is the main reason of material heating and arising of too high temperature. 


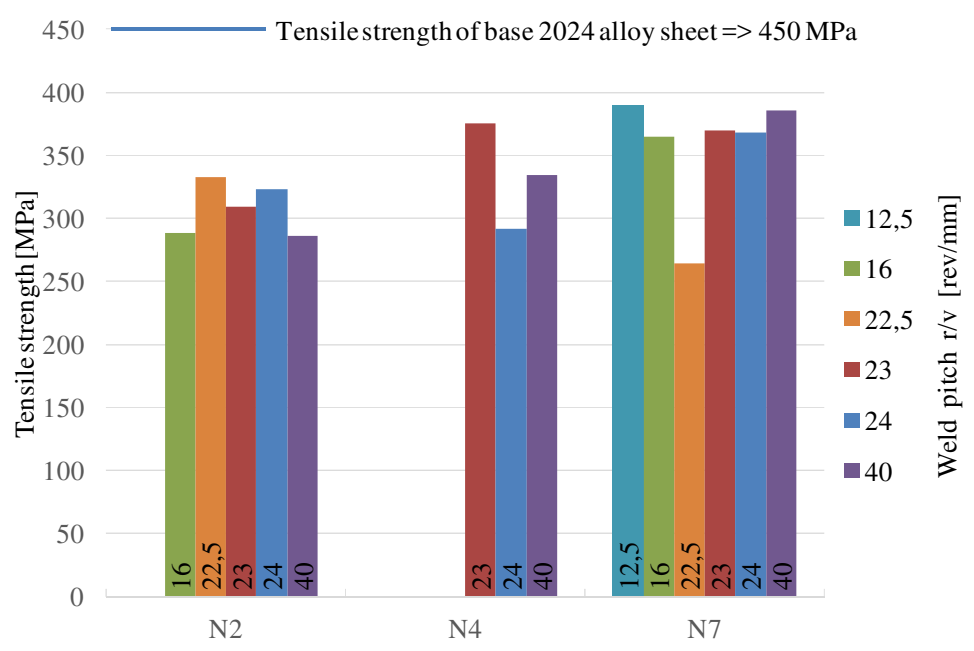

Fig. 4. Tensile strength of FSW joints versus tool geometry and weld pitch
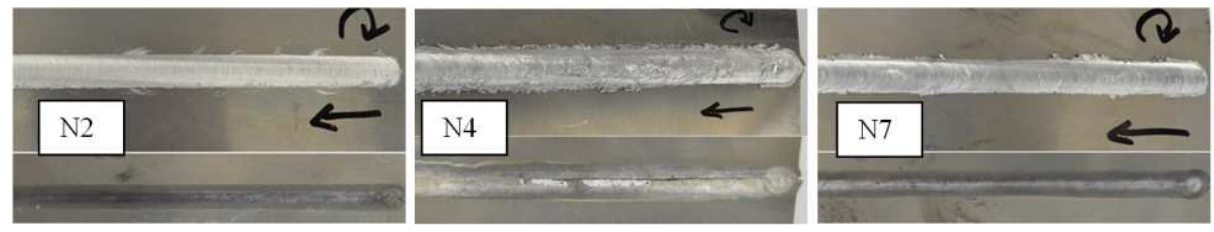

Fig. 5. The face and the root of the FSW joints manufactured with different tools with weld parameters: advance feed $-100 \mathrm{~mm} / \mathrm{min}$, rotation $-2250 \mathrm{rev} / \mathrm{min}$

Because the zones of FSW joint have different resistances to deformation, due to differences in grain size, precipitate size and distribution of grains, the structural notch lowers the tensile strength and the strain of the FSW joint. So, the tensile curve of the base material is higher and longer than the curve of FSW joint (Fig.6).

For all specimens, tested in the tensile test, fracture always occurred in the retreating side, and as it can be estimated from Figure 7; it increases on the border of HAZ and TMAZ in the joint area. It can be concluded that retreating and advancing sides have different strength and the strength of the retreating side is lower. This result is in a good agreement with literature data, e. g. [1], where in the precipitation hardened aluminium alloys, FSW results in a severe softened region in the HAZ, which is basically characterized by the dissolution/coarsening of precipitates during the thermal cycle. The softened region is located at the boundary between the TMAZ and HAZ. FSW results in significant microstructural changes within and around the stirred zone in aluminium alloys, what leads to changes in mechanical properties. The solution of heat treatment and aging of welds could homogenize the material microstructure and could be advantageous for tensile behaviour. 


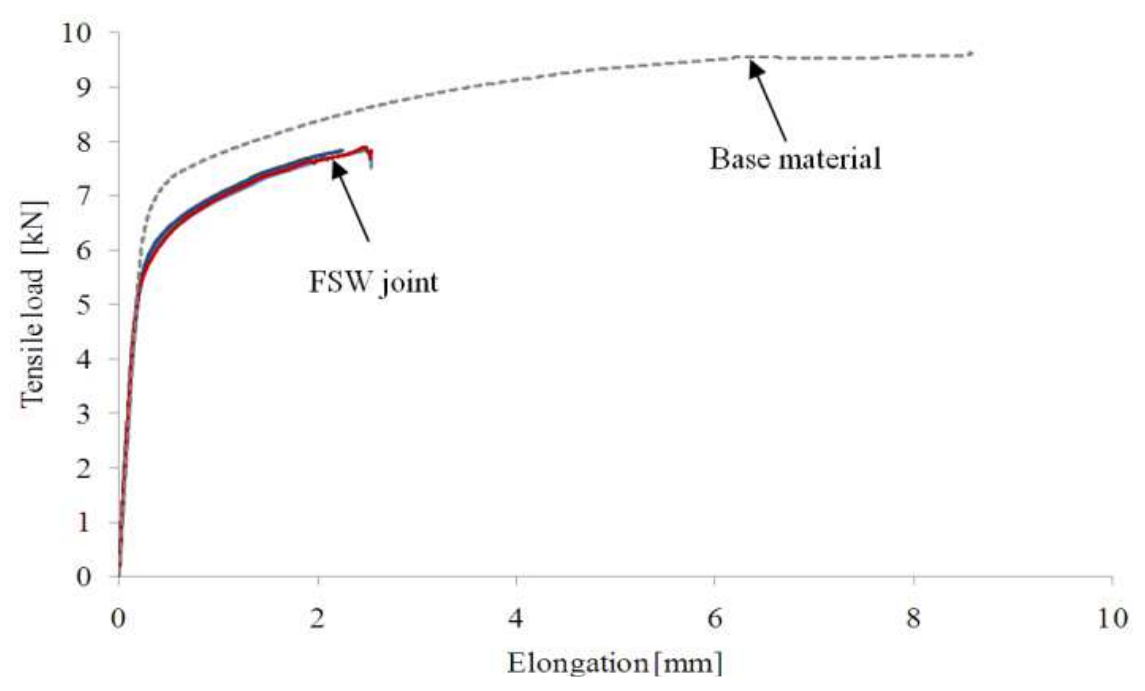

Fig. 6. Tensile test characteristics of the base material and FSW joint (aluminium alloy 2024 T3)

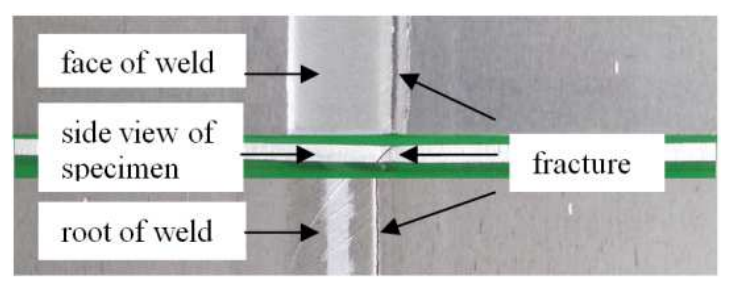

Fig. 7. FSW specimen after tensile test

\section{Conclusions}

Optimum values of tool rotation speed and travel rate were determined for each tool and finally the optimum tool has been found out. The following points have been clarified.

1. The experimental results show a good efficiency of friction stir welding of 2024 aluminium alloy thin sheets (thickness $1.6 \mathrm{~mm}$ ). Although the mechanical properties of the FSW joint are lower than the same of the base material the joint quality is comparable with obtained by conventional welding methods.

2. The FSW tool geometry is very important for the joint quality. The optimal shape and size of tool pin and shoulder should be adjusted to the joined sheet's material and its thickness. In the case of tested 2024 aluminium alloy sheets the best results were obtained for the tool N7, which pin and collar diameters were equal respectively 4 and $12 \mathrm{~mm}$.

3. The good quality and high strength FSW joints need to determine optimal velocities of welding tool. Too large transverse speed of the tool can cause 
formation of a void in the joint area, too large rotational speed can be the reason of the temperature increase and overheating the joint zone.

4. The structure and properties of FSW joint are not symmetrical according to welding line. There are differences between advancing and retreating sides of the joint. Tensile test specimen always fractures in the retreating side.

\section{References}

[1] Mishra R.S., Ma Z.Y.: Friction stir welding and processing, Mat. Sci. Eng., 50 (2005) 1-78.

[2] Seidel T.U., Reynolds A.P.: Visualization of the material flow in AA2195 friction-stir welds using a marker insert technique, Metall. Mat. Trans. A, 32A, (2001) 2879-2884.

[3] Meilinger A., Török I.: The importance of friction stir welding tool, Production Proc. Systems, 6 (2013) 25-34.

[4] Dwivedi S. P.: Effect of process parameters on tensile strength of friction stir welding A356/C355 aluminium alloys joint, J. Mech. Sci. Technol., 28 (2014) 285-291.

[5] Lorrain O., Favier V., Zahrouni H., Lawrjaniec D.: Understanding the material flow path of friction stir welding process using unthreaded tools, J. Mat. Proc. Technol., 210 (2010) 603-609.

\section{WPLYW GEOMETRII NARZEDZIA DO ZGRZEWANIA \\ TARCIOWEGO Z MIESZANIEM NA WYTRZYMAŁOŚĆ NA ROZCIĄGANIE POŁĄCZENIA}

\section{Streszczenie}

Ze względu na odpowiednie właściwości mechaniczne, stop aluminium 2024 idealnie nadaje się do zastosowania w przemyśle lotniczym i samochodowym, natomiast ze względu na słabą spawalność nie jest szeroko stosowany w innych gałęziach przemysłu. Aby przezwyciężyć ten problem, przeprowadzono eksperymenty zgrzewania tarciowego z mieszaniem (ZTM) blach ze stopu aluminium $2024 \mathrm{z}$ udziałem różnych narzędzi oraz w warunkach różnych najważniejszych parametrach procesu, to znaczy prędkości obrotowej i prędkości przemieszczania narzędzia zgrzewającego. Aby zbadać wpływ parametrów procesu ZTM na wytrzymałość mechaniczną połączenia, dla każdego narzędzia, określono wytrzymałość na rozciąganie w funkcji parametrów procesu ZTM. Optymalne wartości prędkości obrotowej oraz prędkości przemieszczania zostały określone dla każdego narzędzia, tak aby w końcu znaleźć optymalne narzędzie.

Słowa kluczowe: zgrzewanie z przemieszaniem, geometria narzędzia do ZTM, stop aluminium 2024, test rozciągania

DOI: $10.7862 / \mathrm{rm} .2016 .23$

Otrzymano/received: $10.10 .2016 r$.

Zaakceptowano/accepted: 10.12.2016 r. 